\title{
連結系汽水湖に遡上する高塩分水塊の挙動と その制御に関する基礎的研究 \\ FUNDAMENTAL INVESTIGATIONS ON SALINE WATER CURRENT ADVANSING INTO A BRACKISH LAKE BY LABORATORY TESTS AND 3D COMPUTATIONS
}

\author{
木村 一郎 1 ・寺本 敦子 2 ・小畑めぐみ 3 ・細田 尚 4 \\ Ichiro KIMURA, Atsuko TERAMOTO, Megumi OBATA and Takashi HOSODA \\ 1正会員 博 (工) 松江工業高等専門学校助教授 環境・建設工学科（†690-8518 松江市西生馬町14-4） \\ 2正会員 博 (工) 松江工業高等専門学校助手 環境・建設工学科（干690-8518 松江市西生馬町14-4） \\ 3学生員 松江工業高等専門学校専攻科 生産・建設システム工学専攻（†690-8518 松江市西生馬町14-4） \\ 4 正会員 工博 京都大学大学院教授 工学研究科都市社会工学専攻（二606-8501 京都市左京区吉田本町）
}

\begin{abstract}
This paper descries predictions of saline water current advancing into brackish lakes in series by means of laboratory tests and 3D computations. The numerical model was tuned through the comparison with results of the laboratory tests performed using a water tank which was made of acrylic acid resin composed of two rectangular model lakes connected with a narrow channel. The present numerical model could reproduce reasonably the fundamental aspect of the flow behavior of the density current when we used a proper tuned vertical eddy viscosity coefficient. In order to control the behavior of advancing saline water, we tried to use a $1 / 4$-sphere type block proposed by Komatsu et al. The experimental and numerical results showed that the blocks are effective to decelerate the density front and decrease the density of saline water near the bottom of the lake, thought the computations could not capture sufficiently the upwelling current triggered by the blocks.
\end{abstract}

Key Words : Brackish lake, Density mixing current, 3D turbulent flow computation, Flow control block

\section{1. はじめに}

宍道湖・大橋川・中海系はわが国の代表的な汽水湖であ るとともに, 連結汽水域としての特殊性も併せ持っている. 宍道湖の汽水性を維持する機構は大橋川からある条件のも とで間欠的に高塩分の水塊が遡上することによるが, この高 塩分水塊が往々にして貧酸素であるため, 宍道湖の生態系 に打撃を与える場合があり, 特にシジミやコノシロの大量斃 死との関連性も指摘されている. このため, 宍道湖に遡上寸 る水塊に関する詳細なメカニズムの解明と, 塩分挙動の制 御方法の構築が急務となっている1).

本研究は, 汽水域における生態系の保全の観点から連 結河川を通じて汽水湖に遡上寸る高塩分水塊の挙動とその 制御方法を検討寸るための基礎データの取得をめざし, 単 純化したアクリル製実験水槽による塩水混合実験と, 三次元 数值解析モデルによる実験スケールでのシミュレーションを 実施するものである. さらに, 生態系への高塩分貧酸素水 塊の影響を緩和するため, 高塩分水塊の遡上を制御するこ とを目的として, 小松らが提案する1/4球型の流況制御ブロッ クの適用の可能性とその効果についても検証する 2 .3. この 制御ブロックは, 内湾などの比較的潮汐が大きい水域の海 水交換促進などを目的とした流況制御に用いられてきたも
のであるが, 湧昇流生成の効果)を有することから, 汽水流 動場に配置することにより塩分成層を制御する効果も期待 できる.このような視点での流況制御ブロックの活用手法が 確立すれば, 比較的安価に, かつ外的エネルギーの供給 無しに継続的な汽水環境改善効果が期待できるため経済 的であり，実用的意義は高いと考えられる。

今回は研究の基礎段階として, 単純地形を対象とした室 内模型実験と, 実験スケールでの数值解析を行う. 最初に 現象の基本特性の把握と数值解析の検証データの取得を 目的とし，実地形を単純化した模型水槽を用いた実験を行う。 次に実験の水理条件を対象に数值シミュレーションを行い, 実験結果と数值解析結果の比較を通じてモデルの妥当性 を検証する. 次に流況制御ブロックを導入した模型実験と数 值シミュレーションを実施し, ブロックが密度成層に及ぼす 影響について考察する.

\section{2. 水理模型実験}

\section{（1）実験の概要}

実験は，図-1に示すようなアクリル製水路を用いて行わ れた.この水路は, 矩形水域を細い水路で結合した形状と なっており, 斐伊川・宍道湖・大橋川・中海・日本海系を想定 



図-1 実験水槽の概要

表-1 水理模型実験の条件

\begin{tabular}{c|c|c|c|c}
\hline Case & $\begin{array}{c}\text { depth of } \\
\text { lake 2 }(\mathrm{h})\end{array}$ & $\begin{array}{c}\text { depth of } \\
\text { lake 1 }\end{array}$ & $\begin{array}{c}\text { width of } \\
\text { river 1 }(\mathrm{B})\end{array}$ & $\begin{array}{c}\text { salt } \\
\text { density }\end{array}$ \\
\hline \hline $\mathrm{A} 1$ & $2(\mathrm{~cm})$ & $5(\mathrm{~cm})$ & $4(\mathrm{~cm})$ & $3(\%)$ \\
\hline $\mathrm{A} 2$ & $3(\mathrm{~cm})$ & $6(\mathrm{~cm})$ & $4(\mathrm{~cm})$ & $3(\%)$ \\
\hline $\mathrm{A} 3$ & $4(\mathrm{~cm})$ & $7(\mathrm{~cm})$ & $4(\mathrm{~cm})$ & $3(\%)$ \\
\hline \hline B1 & $3(\mathrm{~cm})$ & $6(\mathrm{~cm})$ & $4(\mathrm{~cm})$ & $3(\%)$ \\
\hline B2 & $3(\mathrm{~cm})$ & $6(\mathrm{~cm})$ & $4(\mathrm{~cm})$ & $2(\%)$ \\
\hline B3 & $3(\mathrm{~cm})$ & $6(\mathrm{~cm})$ & $4(\mathrm{~cm})$ & $1(\%)$ \\
\hline \hline $\mathrm{CA} 1$ & $4(\mathrm{~cm})$ & $7(\mathrm{~cm})$ & $4(\mathrm{~cm})$ & $3(\%)$ \\
\hline $\mathrm{CA} 2$ & $4(\mathrm{~cm})$ & $7(\mathrm{~cm})$ & $2(\mathrm{~cm})$ & $3(\%)$ \\
\hline $\mathrm{CB} 1$ & $2(\mathrm{~cm})$ & $5(\mathrm{~cm})$ & $4(\mathrm{~cm})$ & $3(\%)$ \\
\hline $\mathrm{CB} 2$ & $2(\mathrm{~cm})$ & $5(\mathrm{~cm})$ & $2(\mathrm{~cm})$ & $3(\%)$ \\
\hline
\end{tabular}

し,1/25000程度のスケールで単純化したものとなっている. ただし, 鉛直方向と河川部について現象の見易さを考慮し 縮尺を大きくとった. 今回の実験では斐伊川(river 2)と日本 海(sea 1)に相当する部分には仕切りを入れて検討対象外と し, 二湖一河川(lake 1, lake 2, river 1)の最も単純な連結汽水 系を対象とした。

実験にあたっては, 中海と宾道湖の境界 (lake 1 とriver 1 の境界)に相当する箇所に仮の仕切りを入れておき, 中海 (lake 1)には着色した塩水を, それ以外の領域 (lake 2およ びriver 1)には淡水を同水深で入れ，ある瞬間に仕切りを取 り除くことにより密度流を生じさせた. なお, 淡水は水道水, 塩水は食塩を水道水に溶か儿た濃度1，2，3\%のものを用い

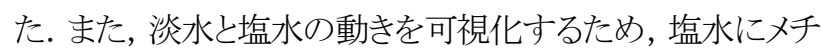
レンブルーあるいは緑色入浴剤で着色した. 仕切りを取り去 る瞬間を実験開始時刻 $\mathrm{t}=0$ とし, これ以降の流動の状況を側 方からビデオカメラで連続撮影し, 上方からはデジタルス チールカメラで5秒おきに撮影した. また, lake 2 内の3点に ついては, 底面より $3.3 \mathrm{~mm} の$ 位置で塩分濃度計(KENEK製) により塩分濃度の時間変化を計測した。

実験の条件は，水深，塩分濃度，連結河川(river 1)の 川幅を変化させた表-1に示す 12 通りの条件で行われた。

\section{（2）塩水遡上の基本特性に関する実験結果と考察}

\section{a) 湖への塩水遡上現象}

実験においては表-1に示寸全てのケースに共通して以 下に示すような現象が観察された。

まず, 仕切り板を取ると, 塩水は淡水の下に潜り込み二成 層化する.つまり, 弱混合型と呼ばれる混合状態となり, 塩

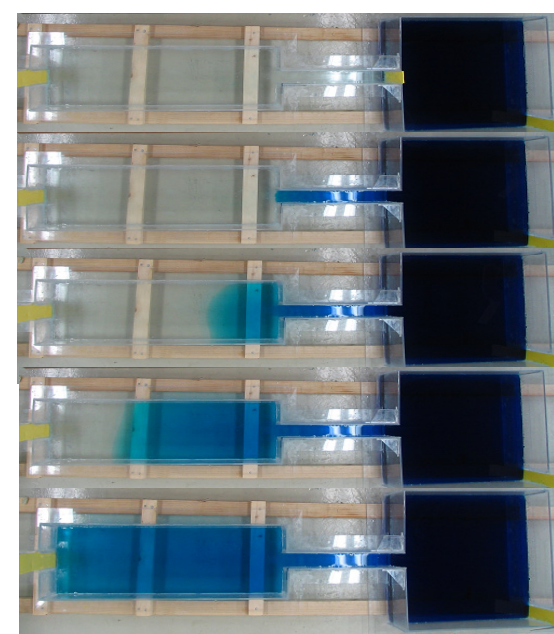

図-2 密度フロントの遡上の様子（撮影閒隔5秒）

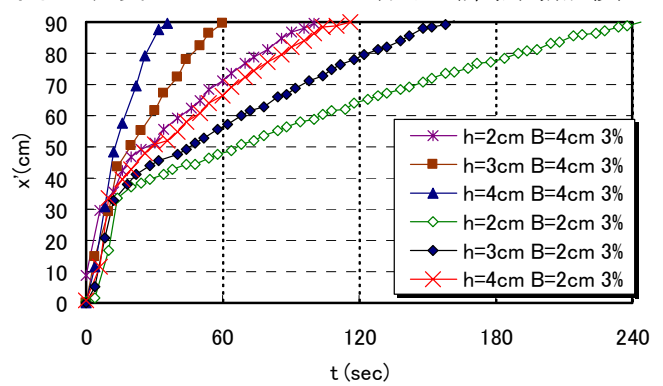

図-3 濃度一定の場合のフロント位置の時間変化 $\left(\mathrm{C}_{0}=3 \%\right)$ 分層が密度フロントを形成し連結河川(river 1)を遡上, 淡水 は海水域一上層として流入して行く. 塩水くさびが淡水湖に 流入すると, いったん横方向に広がるためフロントの進行速 度を遅くなった状態でさらに遡上を続ける. 穴道湖全体に塩 水が行きわたっても塩水の流入, 淡水の中海一の流出が続 き, 最終的に上層に淡水, 下層に塩水となる二成層が形成 され, 流れが落ち着き水路全体でほぼ安定した成層状態と なった. 図-2には密度フロントの進行の様子の一例を示す.

\section{b）密度一定の場合の密度フロントの進行速度}

実験時の写真を元に, 塩水くさびの先端位置を読み取っ た.これを実験ケースごとに横軸に時間, 縦軸に移動距離 を示して塩水フロントの挙動を比較した.

図-3は, 塩分濃度が一定のケースについて, 塩水フロン 卜の挙動を比較したものである.これらの結果から, フロント の進行速度は, 連結河川(river 1)の川幅Bが大きいほど, ま た混合開始断面の水深防大きいほど速いことがわかる.

密度フロントの挙動の支配要因を分析するため, データ の無次元化を試みる. 図-4に示寸ように, 大橋川, 宍道湖 の塩水が到達した領域の面積Aを仕切り挿入部であるriver 1 の流水断面積 $\mathrm{A}_{0}$ で除すことでデータの無次元化を試みた. 無次元化を行った場合の塩水フロントの挙動を図-5に示す. この図では, 全てのケースの時系列がほぼ同一ラインを 辿っている.このことから, lake 1の塩分濃度一定の条件で は, 塩水が到達する領域面積の時間変化は仕切りを置いた 地点の流水断面積に支配されることが指摘される.

\section{c）密度が異なる場合の密度フロントの進行速度}

初期条件の塩分濃度を变化させた場合の実験結果を図一 6に示す.この図から, 塩分濃度が大きいほど進行速度も大 


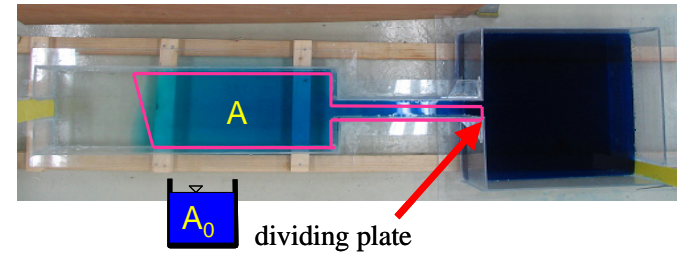

図-4 フロント挙動の無次元化の説明図

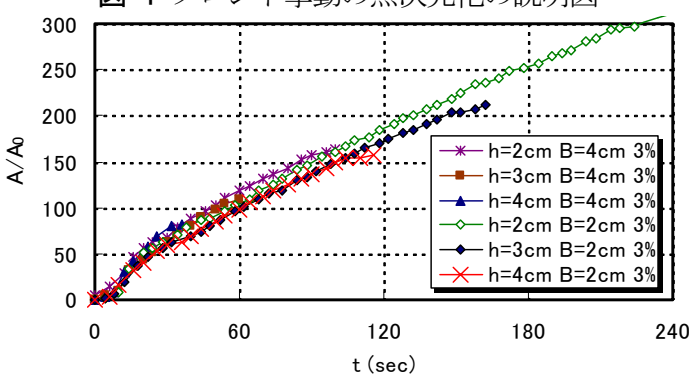

図-5 無次元化されたフロント位置の時間変化 $\left(\mathrm{C}_{0}=3 \%\right)$

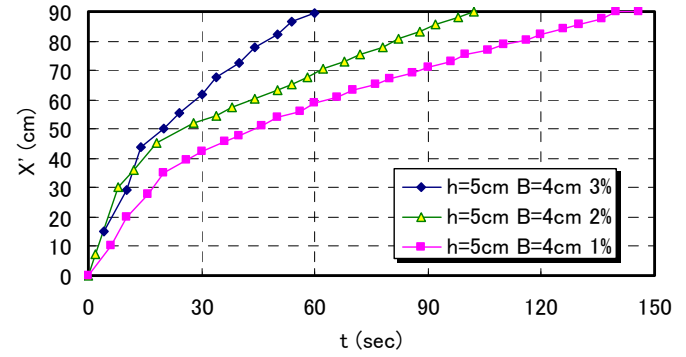

図-6 塩分濃度のみを変化させた場合のフロントの時閒変化

きくなる傾向がわかる. 以上の実験結果をまとめると, 塩水 が到達する領域面積の時間変化は, 連結河川の流水断面 積および塩分濃度差で決まることがわかった。

\section{（3）流況制御ブロックの効果に関する実験結果と考察}

\section{a) 流況制御ブロック}

次に, 小松らによる1/4球型流況制御ブロックによる効果を 検討する.このブロックは, もともと潮汐残差流の生成による 閉鎖性水域の水質改善を目的として考案されたものである が, 湧昇流を生成寸る効果があることも指摘されている2,3,4). このため, 密度成層場に設置すれば, 成層強度の緩和など の効果が期待され，外部からのエネルギーの供給を伴わな い新しい成層制御方法しして注目される.この点に着目して, 河川と汽水湖の境界付近にブロックを配置し, 塩分遡上特 性への効果を検討寸る.

図-7に対象とした流況制御ブロックの形状を示す.このブ ロックは順流, 逆流の流れの向きに対し抗力が大きく異なる といら特徵を持っており, 小松らの実験によれば, 抗力係数 は順流に対してはCd=0.7, 逆流では $\mathrm{Cd}=1.7$ 程度の值をとる ことが指摘されている(図-7参照 $)^{2)}$. 本研究では湧昇流の 発生を期待し, 密度フロントの進行に対して逆流方向にブ ロックを配置する. ブロックの配置場所としては, 流速の大き い連結河川中に設置することが最も効果が大きいと思われ るが, 河川法の関係から実現は困難と思われる. したがって, 連結河川から淡水湖に流入した直後の位置に設置すること とする. 配置形状としては, 図-8に示寸3通りとした. 用いた ブロックのスケールは, 直径 $2.0 \mathrm{~cm}$ の球を $1 / 4$ に割ったものと した. ブロックの模型の作成は, 直径 $1.8 \mathrm{~cm}$ のガラス玉に紙



図-7 1/4球型流況制御ブロックと抗力係数

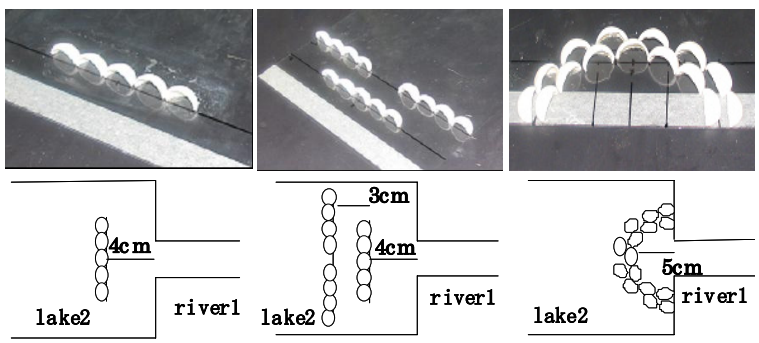

図-8 ブロック配置のパターン（左からCase BL1, BL2, BL3）

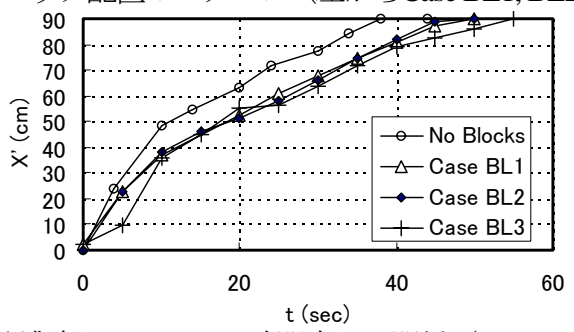

図-9 塩分濃度とフロントの時間変化の関係 $(\mathrm{h}=3 \mathrm{~cm}, \mathrm{~B}=4 \mathrm{~cm})$

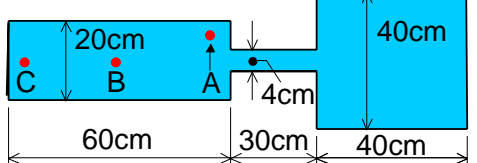

図-10＼cjkstart塩分濃度センサー配置図 ( $\mathrm{z}=3.3 \mathrm{~mm})$

粘土を厚さ $1.0 \mathrm{~mm}$ で均一に巻きつけ, $1 / 4$ に切り出した後, 防水スプレーを施すことにより作成した. 水深hに対するブ ロック高 $\mathrm{h}_{\mathrm{b}}$ の比は $\mathrm{h}_{\mathrm{b}} / \mathrm{h}=1 / 3$ である. この值は, 従来の検討が 概ね $\mathrm{h}_{b} / \mathrm{h}=1 / 4$ 以下でなされていること, 実地形に対する適用 可能性等を考慮すると若干大きいが, ブロックの効果を明瞭 化する意味からこのようなスケールを設定した.

\section{b) 結果の考察}

図-9は,ブロックを挿入した場合の3通りとブロック無しの 場合の実験における塩水フロントの挙動を示したものである。 この条件におけるレイノルズ数は, フロント進行速度を代表 流速, ブロック高を代表長とすると, およそ200〜300となる. 図から, ブロックを挿入することにより,ブロックに密度フロン トが到達し，それを乗り越えるときに一旦減速すること，また その後のフロント進行速度もブロックの無いケースと比較し てみると, 若干遅くなっていることが確認される。

実験では図-10に示寸3点について導電率計により塩分 浱度変化を測定した. センサー設置高は底面より $3.3 \mathrm{~mm} と し$ た. 図-11は $\mathrm{h}=3 \mathrm{~cm}$ の場合のブロック無し(Case NB), Case BL1，BL2について濃度変化を示したものである. 最も上流 のA点では, 密度フロントの到達時間に大きな差は無いが, 濃度の上昇速度はブロックを設置した場合の方が大きい. こ れは, ブロックに遮られた密度フロントが側方に広がり,ブ ロックが無い場合よりも早くA点に高塩分層が到達するため と考えられる. 一方, B点では濃度上昇の開始時刻が異なり, Case NBに比べてCase BL1では約4秒, Case BL2では約11 秒の遅延がみられる. また, $\mathrm{t}=50 \sim 90(\mathrm{sec})$ 付近では, 濃度 


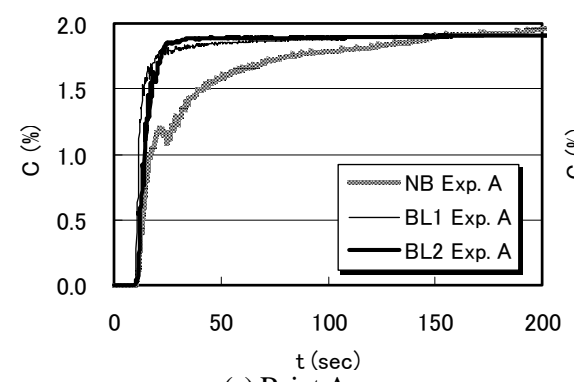

(a) Point A



(b) Point $\mathrm{B}$

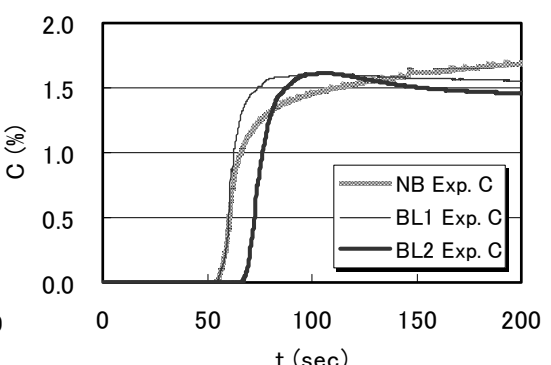

(c) Point C

図-11 実験における濃度変化の時系列の比較（ $\mathrm{h}=3 \mathrm{~cm}, \mathrm{~B}=4 \mathrm{~cm}$, Case NB, BL1, BL2）

の上昇速度に大きな差がみられ, Case BL2では一旦濃度 が下降した後, 上昇に転ずるといら特徴的な上昇曲線を示 している.一方, 点Cでは, Case NBとCase BL1では濃度上 昇開始時刻に差がみられないが, Case BL2では約12秒の 遅延がみられる.これらの結果より, 流況制御ブロックは密 度フロントの到達を遅らせるとともに, lake 2の中央付近では 濃度の急激な上昇を抑制する効果があることがわかった。

\section{2. 数值解析モデルの概要}

\section{（1）数值解析モデルの概要}

a）基礎式

本研究で用いる基礎式は，底面形状に適合し，水面の 移動とともに格子も移動する移動一般曲線座標系の基礎 式であり，Boussinesq近似を用いている．また，圧力に は静水圧近似を用いる。計算格子は $\sum$ 座標的な扱いとす るため, 鉛直方向を $\xi^{3}(\zeta)$ 方向に一致させる. 基礎式 の具体的な表記を次に示す, ${ }^{5,6}$.

[連続式]

$$
\frac{1}{\sqrt{g}} \frac{\partial V^{\alpha} \sqrt{g}}{\partial \xi^{\alpha}}=0
$$

$[\xi, \eta$ 方向運動方程式 $]$

$$
\begin{aligned}
& \frac{\partial V^{i}}{\partial t}+\nabla_{j}\left[V^{i}\left(V^{j}-W^{j}\right)\right]+V^{i} \nabla_{j} W^{j}+V^{j} \nabla_{j} W^{i} \\
& =\frac{\rho}{\rho_{0}} G^{i}-\frac{1}{\rho_{0}} g^{i j} \frac{\partial p}{\partial \xi^{j}}+\nabla_{j}\left[-\overline{v^{i} v^{j}}\right]+2 v \nabla_{j} e^{i j}
\end{aligned}
$$

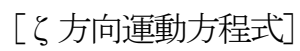

[密度輸送方程式]

$$
\partial p / \partial z=-\rho g
$$

$$
\frac{\partial \rho}{\partial t}+\nabla_{j}\left[\rho\left(V^{j}-W^{j}\right)\right]+\rho \nabla_{j} W^{j}=\nabla_{i}\left\{K_{\beta} g^{i j} \frac{\partial \rho}{\partial \xi^{j}}\right\}
$$

ここに, $t$ : 時間, $x_{j}$ :物理空間座標, $\xi^{\mathrm{j}}$ : 計算空間座標, $V_{j}$ : 流速ベクトルの反変成分, $W^{j}$ : 格子移動速度の反変成分, $g^{i j}$ : 計量テンソルの反変成分, $\nabla_{\mathrm{j}}$ は共変微分, $v^{\mathrm{j}}:$ 乱れ速度 ベタルルの反変成分, $p$ : 圧力, $v$ : 動粘性係数, $\rho$ : 流体の 密度, $k$ : 乱れエネルギー, $\varepsilon$ : 乱れエネルギー散逸率, $F$ ${ }^{j}$ :重力ベタトルの反変成分, $\rho_{0}$ : 基準密度をそれぞれ表す. 計量テンソル等は次式で表される.

$$
g_{i j}=\frac{\partial x^{k}}{\partial \xi^{i}} \frac{\partial x^{l}}{\partial \xi^{j}} \delta_{k l}, g^{i j}=\frac{\partial \xi^{k}}{\partial x^{i}} \frac{\partial \xi^{l}}{\partial x^{j}} \delta_{k l}, g_{i j} g^{j k}=\delta_{i}^{k}
$$

ここに，xiはデカルト座標系を表す．また，
表-2 数值解析の条件（ブロック配置は図-8参照）

\begin{tabular}{c|c|c|c|c}
\hline Run & $\begin{array}{c}\text { Depth of } \\
\text { lake 2 (h) }\end{array}$ & Salinity & $\begin{array}{c}\text { Width of } \\
\text { river 1 (B) }\end{array}$ & Block \\
\hline 1 & $3(\mathrm{~cm})$ & $3.0 \%$ & $4 \mathrm{~cm}$ & NB (No blocks) \\
\hline 2 & $3(\mathrm{~cm})$ & $3.0 \%$ & $4 \mathrm{~cm}$ & BL1 \\
\hline 3 & $3(\mathrm{~cm})$ & $3.0 \%$ & $4 \mathrm{~cm}$ & BL2 \\
\hline \multicolumn{5}{c}{$g=\operatorname{det}\left[g_{i j}\right]$}
\end{tabular}

である，さらに， $\nabla_{\mathrm{j}}$ は共変微分を表し，例えば，ある心゙ クトルの反変成分 $A^{\mathrm{k}}$ に関しては, 次のようになる.

$$
\nabla_{i} A^{k}=\frac{\partial A^{k}}{\partial \xi^{i}}+A^{j} \Gamma_{i j}{ }^{k}
$$

ここに， $\Gamma_{\mathrm{ij}}{ }^{\mathrm{k}}$ は次のクリストッフェル記号である.

$\Gamma_{i j}{ }^{k}=\left\{\begin{array}{c}k \\ i j\end{array}\right\}=\frac{1}{2} g^{k m}\left(\frac{\partial g_{j m}}{\partial \xi^{i}}+\frac{\partial g_{i m}}{\partial \xi^{j}}-\frac{\partial g_{i j}}{\partial \xi^{m}}\right)=\frac{\partial \xi^{k}}{\partial x^{p}} \frac{\partial^{2} x^{p}}{\partial \xi^{i} \partial \xi^{j}}(8)$ なお，流速べクトルの反変成分 $\left(V^{k}\right)$ と直交成分 $\left(U^{k}\right)$ は次 の関係 (chain rule) により変換される.

$$
V^{i}=\frac{\partial \xi^{i}}{\partial x^{j}} U^{j}, \quad U^{i}=\frac{\partial x^{i}}{\partial \xi^{j}} V^{j}
$$

なお，式(1)-(9)の詳細や誘導等は文献を参照 5 , されれたい.

\section{b) 渦動拡散係数}

鉛直方向の渦動拡散係数 $\mathrm{K}_{\mathrm{z}}$ は, Munk \& Andersonらの モデルにより, 次のように与える ${ }^{7,8,9)}$.

$$
v_{z}=v_{z 0}\left(1+a R_{i}\right)^{\alpha}, \quad K_{z}=K_{z 0}\left(1+b R_{i}\right)^{\beta}
$$

ここに, $R_{i}$ はリチャードソン数であり, 次式で表される.

$$
R_{i}=-\frac{g}{\rho}\left(\frac{\partial \rho}{\partial z}\right)\left(\frac{\partial U}{\partial z}\right)^{-2}
$$

ここに，Uはデカルト座標系での流速 $\left(u_{x}, u_{y}\right)$ を用いて,

$$
U=\sqrt{u_{x}^{2}+u_{y}^{2}}
$$

となる．また， $v_{z 0}, \mathrm{~K}_{z 0}$ は密度勾配が無いときの值であ り，試行錯誤の結果，次の值を用いた。

$$
v_{z 0}=K_{z 0}=0.1 \mathrm{~cm}^{2} / \mathrm{s}
$$

また，モデル定数については次の值を用いている.

$$
a=10, \quad b=3.33, \quad \alpha=-0.5, \quad \beta=-1.5
$$

水平渦動拡散係数については実験結果との適合性を考慮 次のように与えた.

$$
v_{h}=K_{h}=0.2 \mathrm{~cm}^{2} / \mathrm{s}=\text { const. }
$$

\section{c）計算法の概要}

計算法は有限体積法とし, 安定性と有限体積法への親和 性を考慮して, 圧力, 物質濃度を格子の中央で, 流速べク卜 ルの成分を格子側面で定義する完全スタガード格子系を用 いる. 計量テンソル, クリストッフェル記号等は格子点上で定 




(a) Horizontal plane at the bottom

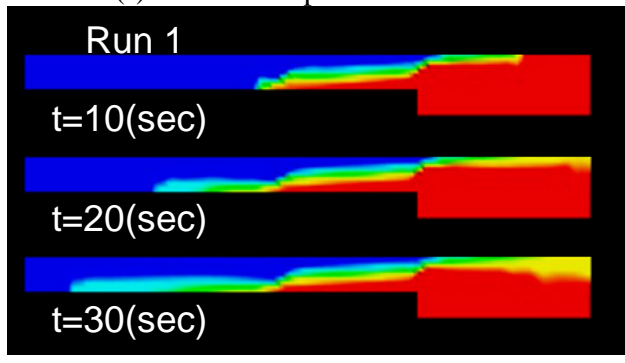

(b) Vertical plane along the center line

図-12 塩分濃度コンター (Case NB（ブロック無し）)

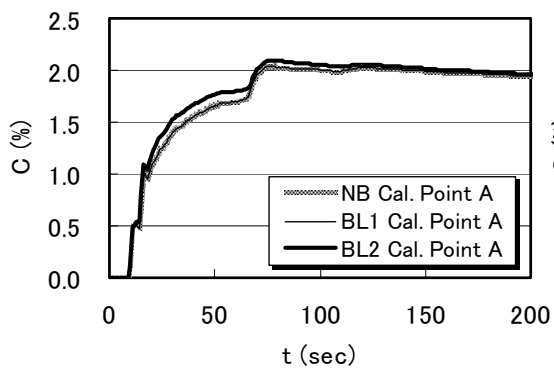

(a) Point A



(b) Point B

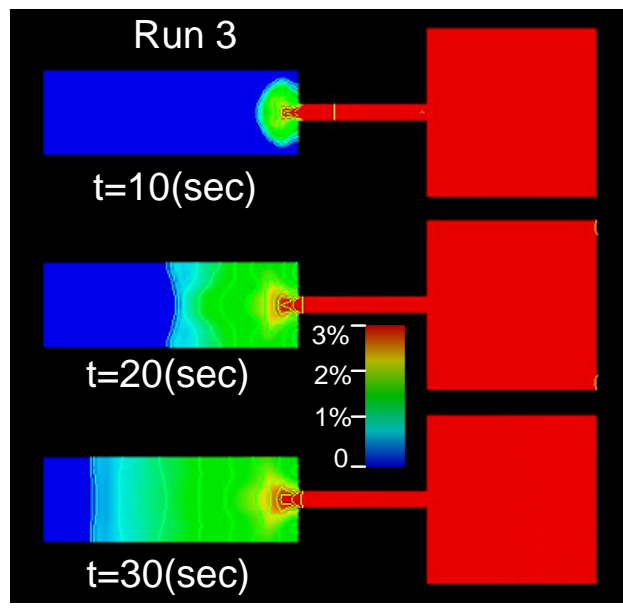

(a) Horizontal plane at the bottom

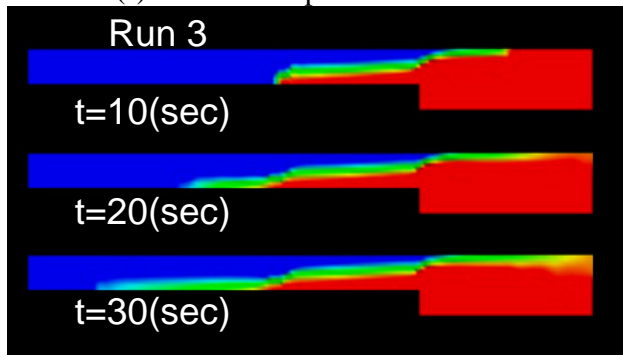

(b) Vertical plane along the center line

図-13 塩分濃度コンター (Case BL2)

図-14 数值解析における濃度変化の時系列の比較（Case NB, BL1, BL2） ( $\mathrm{h}=3 \mathrm{~cm}, \mathrm{~B}=4 \mathrm{~cm})$

義し, 計算の過程で必要となる位置の值については, その 都度内挿により求めた. これは計算機記憶容量の節約のた めである5). 計算は表-2に示す3つの条件で行い結果を比 較する. 流況制御ブロックの効果の数值計算への導入は, 次の抗力の式を用いる.

$$
F=\frac{1}{2} \rho C_{d}\left|V^{2}\right| A_{r}
$$

ここに, $\mathrm{C}_{\mathrm{d}}$ : 抗力係数 (順流で0.7, 逆流で1.7) , $\mathrm{A}_{\mathrm{r}}$ : ブロックの鉛直面への投影面積である.

計算格子の初期格子幅はx方向 : $1 \mathrm{~cm}, \mathrm{y}$ 方向 : $1 \mathrm{~cm}, \mathrm{z}$ 方向 : $0.25 \mathrm{~cm}$ と, 全格子数は 22800 格子となった.

\section{(2) 数値解析結果の考察}

\section{a) フロント形状の比較}

図-12，13は，それぞれCase NB，BL2における計算結果 の塩分濃度分布を示したものである. 底面水平面と, 水路中 央に沿う鉛直断面について. 計算開始後 $\mathrm{t}=10(\mathrm{sec}), 20(\mathrm{sec})$, 30(sec)の3時刻について示している. これらの密度フロント の挙動を実験におけるビデオ画像や静止画像と比較すると 本数值解析モデルは塩分遡上特性を少なくとも定性的には


面内の分布に着目すると, Case BL2では密度フロントの形 状がブロックの影響により横断方向に引き伸ばされ, 円弧状 のフロント形状をなすCase NBとは異なった特性を示す.ま た,2ケースにおける鉛直断面コンターより, Case BL2では フロント進行速度がCase NBより小さく, ブロックにより塩分遡 上が抑制されることがわかる. しかしながら, ブロック位置に おける湧昇流の発生はこの図からは明確には確認できない.

図-14は, 数值解析結果におけるA〜C点における濃度変 化を示したものである. 実験結果(図-11)と比較すると, 数值 解析結果ではブロックの無い場合とブロックが存在する場合 との差が小さいことがわかる. これは, 数值解析におけるブ ロックの影響を抗力のみを考慮して評価しており, ブロック による局所流構造の変化を十分反映できないためと考えら れる. ここでいら局所流とはブロックによるの左右, 上方への 流れの迁回, 剥離や湧昇流などの乱流の誘起などが含ま れる.この点の改善には, ブロック周辺の局所的な乱流構 造に関する詳細な実験や数值シミュレーションを実施しここ れらの結果を反映させるブロックのモデル化の方法を検討 


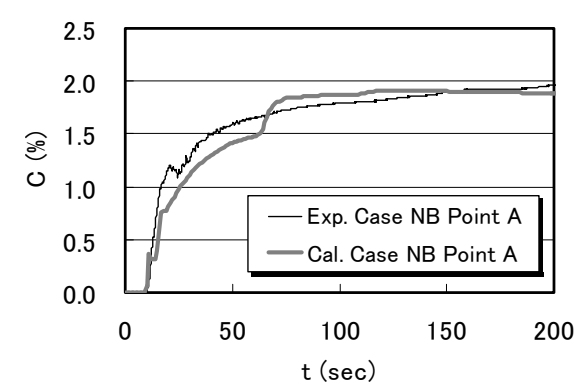

(a) Point A

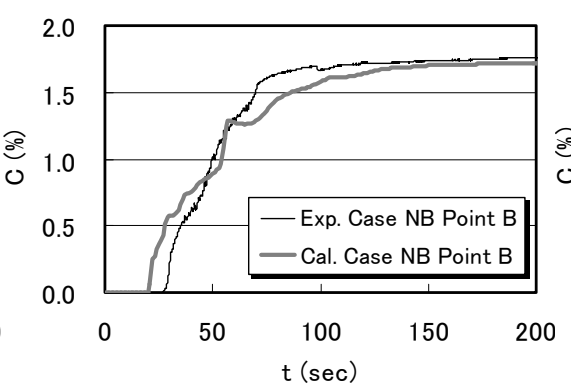

(b) Point B



(c) Point $\mathrm{C}$

図-15 実験と数值解析における濃度変化の時系列の比較 (Case NB)

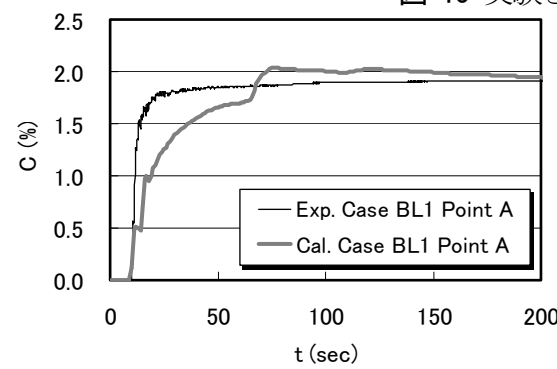

(a) Point A



(b) Point B

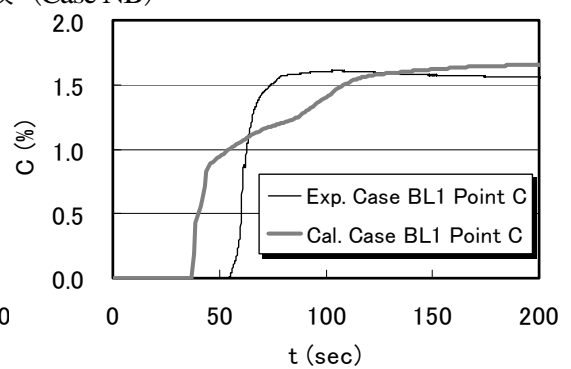

(c) Point C

図-16 実験と数值解析における濃度变化の時系列の比較（Case BL1）

\section{していく必要があろう。}

図-15は, Case NBにおける濃度変化の様子を実験と計算 で比較したものである. 点Aと点 $\mathrm{B}$ に関しては実験結果と計 算結果の一致は概ね良好で, フロント到達時刻, 濃度上昇 過程ともに比較的よく適合している. しかし，点Cに関しては 濃度の立ち上がり時刻が実験に比べてかなり早く再現され ている.この理由は不明であるが, 点Cは下流側の壁面から のフロントの反射の影響もあり, 複雑な密度流構造を呈する ため, モデルの改良に向けてより詳細な実験データの取得 を行う必要があろう. なお, $\mathrm{t}=70(\mathrm{sec})$ 以降の変化については 点Cにおいても計算結果は実験をよく再現している.

図-16は, Case BL1について, 濃度変化の時系列を実験と 計算で比較したものである. 点Aについては, フロントの到 達時刻を良好に再現しており, また前述のブロックの遮蔽効 果による濃度の増加についてもある程度再現できている.し かしながら, ブロック下流側の点 $\mathrm{B}, \mathrm{C}$ では, 密度フロントの 到達時刻が実験よりも相当早くなっている.これは, 図-14の 考察で指摘したように, ブロックによる局所流構造の変化が 数值解析モデルに十分反映されていないためと考えられる.

\section{4. おわりに}

本研究は連結汽水域における塩分遡上とその制御方法に ついて, 水理実験と三次元モデルによる数值解析により検 討を行ったものである. 得られた主な成果を以下にまとめる. (1) $2 つ の$ 湖とそれを結ぶ連結河川とからなる実験装置を用 いて塩分遡上現象の実験を行った. 実験結果の無次元化よ り, 密度フロント進行速度は, 初期の塩分・淡水境界の流水 断面積および塩分濃度に支配されることが示された。

(2) 小松らの提案する $1 / 4$ 球型流況制御ブロックを連結河川 の河口付近に設置した結果, 密度フロントの進行速度と塩 分濃度の急激な上昇を抑制する効果が示された。

(3) 三次元数值解析モデルにより, ブロックが無い場合の塩
分遡上特性は比較的良好に再現された。

(4) ブロック効果を抗力として導入した解析モデルはブロッ ク周辺の局所流構造を再現できないため, ブロックの効果を 十分再現できず, モデル改良の必要性が指摘された.

以上より, 内湾などの比較的潮汐の影響が大きい場を対 象としてきた流況制御ブロックが, 密度フロントの進行を抑 制する効果を有することが指摘された. ただし，これが密度 成層の制御につながるかどうかについては更に検討を要す る. 今後はブロック周辺の局所的流構造の解明と, その影響 の数值解析モデルへ組み込みについて検討を進めたい.

謝辞:本研究の遂行にあたり, 当時松江高専5年松崎健氏(立命館 大) 及び団野紘貴氏 (松江土建) より実験の補助を頂いた. また九 州大院田井明氏からは貴重な資料の提供受けたので謝意を表す。

\section{参考文献}

1) 福岡捷二, 松下, 岡村, 今井, 舟橋: 汽水湖に流入する塩水 の流動特性, 水工学論文集, Vol.48, pp.1405-1410., 2004.

2) 小松他:九州大学環境流体力学研究室報告書「潮汐残差流の 創造・制御による閉鎖性海域の水質改善に関寸る研究」, 1998.

3) 田井明:有明海における海水交換促進技術に関する数值実 験的研究, 九州大学工学部卒業研究, 2004.

4) 矢野真一郎, 斎田, 大原, 石村, 西ノ首, 小松:現地試験によ る流況制御ブロックの湧昇流発生効果の検証, 海洋開発論文 集, Vol.20, pp.881-886, 2004.

5) 木村一郎, 細田尚, 音田慎一郎: 完全スタガード移動一般曲 線座標系における開水路乱流シミュレータの開発, 四日市大 学環境情報論集, Vol.5 pp.145-170, 2002.

6) 木村一郎, 千葉賢, 小畑めぐみ, 細田尚:密度混合流解析一 の移動一般曲線座標モデルの適用に関する二, 三の検討, 水工学論文集, Vol.49, pp.691-696, 2005.

7) 千葉賢, 武本行正:伊勢湾シミュレータの開発・第3 報, 四日 市大学環境情報論集, Vol.3, No.1, pp.19-60, 1999.

8) Munk, W. H., and Anderson, E. R.: Notes on the theory of the thermocline, J. Mar. Res., 3, pp 276-295, 1948.

9)横山長之:海洋環境シミュレーション, 白亜書房, 1993.

(2005. 9. 30受付) 